\title{
Rethink the Educational Potential of the Sporting Experience for the Child between 5 and 11 Years: The Educational Tasks of the Coach
}

\author{
Emanuela Guarcello* \\ University of Turin, Italy
}

*Corresponding Author: Emanuela Guarcello, University of Turin, Italy

\begin{abstract}
The practice of a sport in childhood is an opportunity that is offered to the majority of boys and girls in the period of growth and formation. They face the field, the pool or the gym opening up to a contradictory world, which will test them and present them with challenges, highlighting their limits and the obstacles to face. The young athletes, in this experience, do not have to be alone: in fact they enter a relationship with adult instructors, who become guides and role models for them. But what are, then, the characteristics of being a good coach? This contribution invites us not to focus exclusively on technical skills, suggesting a widening of our vision to deepen the central aspects of the fundamental educational task of the sports instructor.
\end{abstract}

Key Words: sport, children, coach, educational role, potential, ethics

\section{The Sporting Experience For The Child: Problematic Spaces And Educational POTENTIAL}

The practice of sport is a phenomenon that presents a fundamental contradiction because it offers to the child both a significant experience for growth, while on the contrary, as an experience that, if one is not aware of its potential, can have a negative effect on growth itself, to the point of tending towards precocity, sensationalizing and instrumentalization of the child in the name of sports performance.

Within this underlying contradiction it is possible to define a specific problematic space which can be drawn by observing the two different sides.

Sport, on the one hand, offers children the opportunity to do activities that allow them to discover their skills, to practice in comparison with others, to measure themselves with the rules. These are educational experiences which can significantly affect not only the process of defining the identity of the child but also, in the longer term, on one's ability to be - in the future - that active and responsible citizen who can find in sport a model of excellence [2]. These same experiences, however, can be really important only on the condition of finding adults who are aware both of the educational potential latent within the activities themselves, and of the particular mode of management capable of freeing and directing its potential.

The sporting experience, on the other hand, is confronted with a double problem: firstly a scenario of the coach not yet ready to fully grasp the educational sense of sport and in particular its implications in terms of relational practices favouring or disfavouring a balanced growth of the child; secondly is the difficulty the coach finds himself in who, while recognizing the educational value inherent in his role, struggles to "play the child in the field" because he believes the child does not have the appropriate skills, while it is the educational role of doing so, which is not always recognized by the parents or the athletes themselves. This creates uncomfortable situations in terms of managing the relationship with the individual child and with the group, as well as with the parents.

The satisfaction of the condition represented by the presence of competent coaches and overcoming the problems represented by the lack of awareness or the sense of inadequacy and discontent that the coach experiences, are now increasingly central and urgent especially within a particular sporting experience, that which is aimed at children from five to eleven years. The first motivation is reflected 
in the growing spread of sport. Awareness of the centrality and urgency of the problems highlighted attention is focused on that large number of boys and girls who today could suffer a major discomfort in terms of excessive performance expectations, of internalization of abusive and overbearing relational styles, of conduct that does not respect the norms and human values proper to the sporting experience itself.

The second motivation is reflected in the tendencies of coaches not to assume their educational role, which is as crucial and urgent as the very number of children who are fond of the sporting experience. This makes manifest their inability and disinterest in seizing and managing those awkward situations of childhood, which can often be grasped with greater ease and frequency during extracurricular activities and that otherwise risk remaining unacknowledged. Not only does this inability and disinterest relate to the discomfort of the children, but also to their growth in the full and human sense, thus renouncing the opportunity to make the sporting experience a test field that prepares the child to intervene in the world. Both the number of boys and girls involved in sport and the importance of protecting them for their advancement as future adults, make it all the more crucial and urgent today to address, both in gyms and on playgrounds, the problem of childhood malaise in order to train young people to be increasingly able to intervene in the world

Within the athletic experience of the child then opens a problematic space from which a specific question of research is raised: if the sporting experience - thanks to the presence of the coach - has an educational potential, the awareness and management of which are as crucial as they are urgent, how does pedagogical knowledge clarify the boundaries and direct this potential so that sport is an opportunity for growth and self-improvement for the child?

\section{THE EDUCATIONAL POTENTIAL OF THE SPORTING EXPERIENCE}

In working on the reconstruction of theoretically based and operationally meaningful answers to this question, we must instigate a reflection starting from the recognition of the educational potential of the sporting experience, a potential that is promoted thanks to the specific work of the coach, undoubtedly recognized today ${ }^{1}$ - not only in the sports field but also at a social and cultural level - as the lever to promote the technical-tactical potential of the athletic experience. Instead, a second aspect of the work of the coach has struggled to come into the light: this being the leverage to promote not only the technical-tactical potential but also the educational potential of the sport itself. This aspect, although already inscribed in the concept of gymnastés $^{2}$, at the same time is slow to be recognized by the humanities studies: «the studies on coaching in sport have [only] in recent years deepened the theme of the role of the sports coach» [3, p. 87]. A role which conjures the image of an orchestra, indicating how the educational potential of sport is mainly recognized in its being an experience of self-control, compliance with the tasks assigned and functional organisation to achieve the optimum result, given the available resources [4].

This potential can be traced in all the meanings within which the sporting experience in western civilization takes form [5]. In fact, from military sports (paramilitary activities that simulate military ones) to fitness sports (promotion and maintenance of health and well-being), from professional sports to sports-games (recreational activity also defined educational or educational sports ${ }^{3}$ ), the sporting experience - even in being "polysemic" [6, p. 83] - proposes the idea of an instructor who, orchestrating the activity of athletic improvement, leads the athlete towards their maximum potential.

This idea of the coach finds its widest and well-known expression in the path that leads from a sport intended as a game to sport intended as professional competition. It is a path that raises the question of improvement not only in terms of athletic performance but, thinking in particular of the contributions of Peter Arnold [7], in terms of moral improvement. The educational potential of the sporting

\footnotetext{
${ }^{1}$ «The ethos of natural aristocratic superiority forced the Olympic athletes of the first decades of the last century to train in secret or to hide the fact that they used coaches to prepare for sports competitions» [6, p. 7].

${ }^{2}$ Intended as a guide and accompaniment.

${ }^{3}$ The first examples at the beginning of the modern age are the school of "Ca Gioiosa" in Vittorino da Feltre, the Institute of Burgdorf by Friedrich Fröebel, the Institute of Yverdon by Johann Heinrich Pestalozzi, the Salesian Institutes of Don Giovanni Bosco, from the experience of Thomas Arnold's Rugby School [4, p. 90].
} 
experience is therefore fundamentally recognized in the value dimension that permeates the path of athletic preparation and the same competitive framework that immediately leads the child to deal in primis with their goals and secondly comparison with the other. The value dimension is recalled in Arnoldian thought with particular reference not only to the ethical level in general, but rather to the particular value of justice as recalled in the work "A theory of justice" by John Rawls [8].

Within a framework of liberals, the Rawlsian proposal aims to protect human value, in its fundamental definition, of freedom, in which justice represents the "guarantee" of the exercise of individual freedom according to the principle of equality. Starting from this framework, Arnold argues his vision of the educational potential of sport:

The rational subject who plays will not only have reflected, before participating, on the principle that "the law is equal for all", but as a participant he will support and respect the rules of fair play. Knowledge and respect for the rules that make up a sport and govern it are fundamental to this concept and must be accepted in advance and, above all, observed spontaneously in practice. In conclusion, both logically and morally, is that there is only one way to play correctly: to do so according to the rules [7, p. 67].

It is in this sense that Arnold, whom Roberto Farné considers to be «perhaps the most important scholar of the pedagogy of sport» [1, p. 12], recognizes the educational potential not only in the principle of justice but in a particular principle of justice understood «as honesty» [1, p. 65], which within the sporting experience is translated as deliberate and continuous respect of the rules of the "game". This particular aspect clarifies the connection that Arnold himself recognizes between the particular abitus onestus that the sporting experience contributes to build and the wider formation of the "moral character" of the child and the athlete. A training that, while on the one hand represents the highest point of reach for the educational potential of sport, on the other is not interpreted in a deterministic sense as an implicit transfer of moral qualities from sport to the very existence of the person. The formation of character, as the maximum educational potential of sport, is rather read in the sense of possibility, that is, as a test of oneself and of one's own humanity that makes the athlete a person cultured in his entirety, a person who, by playing, is implicitly measured by what he is and what he could become as a future woman or future man: «While some sports, such as trampolining, stimulate boldness, cold-bloodedness and self-control, others such as football exalt group spirit, endurance and determination» $[1$, p. 70$]$.

In a sense not dissimilar, among the first of Cosimo Laneve [9] reconstructions are the boundaries of the educational potential of the sporting experience with particular regard to football, and in particular to the figure of the coach. It is an educational potential recognized in «human formation» [9, p. 194] that is, in the integral formation of the person oriented in an ethical-value sense and aimed at intervening in the world in the name of those same values. Precisely in the light of this potential, not only is a «demonstrative ability» recognized in the instructor, but also a real «sensitivity» necessary to grasp the experiences and feelings of children and young people and to accompany them «to become adults in the fullness of its meaning» [9, p. 195]. It is a crucial sensitivity for the coach, of course, in the accompaniment towards becoming adults, but also in the orientation of the child and then the adult to discover their talent as a person and as an athlete.

Laneve concludes his reflection by referring to a central issue in the discourse on the educational potential of the sporting experience and, in particular, football: if the implicit existence of this potential is undeniable, it cannot be considered fully educational if it is not - as with Spranger [10] brought to awareness, which is accompanied towards its emergence, and if it does not find coaches able to recognize it and manage it in a promotional sense for the child. A question that, since it is still - and above all - as open and crucial today as ever, calls for a commitment to reflection and clarification regarding the educational potential of the sporting experience and the role of the coach as a lever for its actualization.

The teams participating in the championships of the youth categories are entrusted, most of the time, to coaches who are not really experienced. [... ] It is increasingly evident that a close correlation between age and, therefore, the experience of the coach and that of young athletes. [...] As the trainer acquires experience and competence, he gets "promoted" [...] the youth sectors of sports clubs are often considered to be of secondary importance [11, p. 52]. 


\section{THE IDEA OF THE CHILD: THE HORIZON OF THE EDUCATIONAL WORK OF THE COACH}

How do we work on defining the limits of the educational potential of the sporting experience and in particular of the child?

We must refrain from easy positions in favour of the undistinguished and uncritical educational potential of sport.

The axiom borrowed from the common sense that sport contains, in any case, a specific education, which has over time consolidated a close, specific, and all too uncritical relationship of continuity between the theoretical and methodological assumptions of basic sports education, set by those who manage the business related to the spread of the sporting spectacle. This has meant that today educational sport shares the analogous horizon of sense, the theory and the applications of the sport characterized from an increasingly exasperated and precocious agonism, which is the current professionalism that remunerates (few) athletes so much and many more among those who run it.

This phenomenon represents, in my opinion, the main obstacle to the creation of a new educational professionalism capable of giving life to a more conscious and modern teaching of sports practice [12, p. 31].

On the one hand, the recognition of this potential has been slow to arrive, while on the other hand, it is an often nebulous recognition that risks confusing, within the confines of education, what is decidedly alien to it. The definition of this educational process, particularly to arrive at a clarification that is valid and significant, can only start within the framework offered by pedagogical knowledge, which more historically and authoritatively studies the educational and training processes. It is precisely pedagogical knowledge that makes it clear that education cannot be defined and understood from an operational intervention, but rather from the idea that guides the intervention itself. It is not primarily what the coach does to clarify the educational or non-educational sense of the sporting experience, but it is the idea that the coach has with respect to the future man and the future woman that sport therefore can help to define, thanks to this educational potential:

The idea of education and the task of the one who educates always depends on the idea of man and his destiny; and from this derive methods, guidelines and motives from which to draw inspiration. Choosing to accompany young people during their sport involves a precise position towards the person and the sense that physical education can have for his life [3, p. 90].

To Lucien Laberthonnière then [13], we owe the clarification of this central epistemic node for the understanding of the direction, following the boundaries of education, understanding that one cannot dive into a more or even a less educational action before having clarified the idea of the child that such action intends to promote. This priority given to the idea finds its foundation in the very essence of education, that is, of a process that cannot form a child in the sense of being instrumental to the functional needs of the context, but which must promote the child in the sense of their fullest and most humane fulfilment. The risk is high, and in fact not infrequent, that education is misunderstood and descends into just training, making training a purely functional exercise experience for a subsequent competitive preparation. Therefore, it is as relevant as it could possibly be to the achievement of a sports performance and for this reason, of interest for the functioning of the sporting society itself.

In education and in the sports field, it is therefore the child who prevails over sports performance. The child - and their promotion in the human sense - pre-holds true as it represents the end in view of which the educational potential works towards within the sporting experience. Only the clarification of this end, its choosing and its sharing - as it is considered an aim of unparalleled and universal value - can allow the orientation of the potential of sport towards an educational sense and to define the actions that the coach is called upon to put in place for its specific and effective realization.

The idea of a child, that can be placed in a valid and authoritative way to guide the educational work of the coach, although a priority and necessary, is not univocal and cannot be defined in a final way. It cannot therefore be set nor discovered casually or relatively from time to time in individual microexperiences of sports. On the contrary, it must be patiently reconstructed by placing in dialogue the idea of a child that education intends to promote both in the child's universally recognizable humanity, and in their contextualization within the specific terrain of the sporting experience. 
An interesting key to reading, in order to open but certainly not to exhaust the reflection, and to do so by keeping this bifocal view on the idea of a child - as universal as particular - is offered by the "papers" on the rights of children which have succeeded one another over the years and which, especially since 1989, have thought of the sporting experience in all respects as a right of the child, as one of the significant spaces for the child's full and balanced growth. These papers, in fact, promote an idea of the child in a universal sense - of essential value for all children -, and at the same time express the idea of the child from time to time reconstructed from the context within which the paper itself was promoted, therefore an idea historically and culturally located.

Although one of the first papers for the protection and promotion of the rights of the child urged by the work of Janusz Korczak, the Magna Charta Libertatis on the rights of the child (1914-1918) [14], dates back to the first twenty years of the last century, we do not yet find within it an explicit reference to the experience of play and sport, nor do we see any mention of it a little later, in 1924, in the Declaration of the Rights of the Child [15].

It is in 1942 that, with the Thirty Points of Calais [16], we find one of the first references to "body culture" promoted for hygienic-sanitary and moral reasons through gymnastics. It is, however, necessary to wait until 1959 with the Universal Declaration of the Rights of the Child [17] to see an initial and partial recognition of the link between education and «leisure» and «games and recreational activities». They are entertainment, games and activities that in reality, in the sense of the Declaration, do not possess a real educational potential but «must be oriented to educational purposes». Therefore, education intervenes to bend those experiences so that they are not "ends in themselves" but are oriented to accompany the child to «become a useful member of society» (italics are ours). Therefore, if the link between education and sport is in a sense recognized, at the same time it is a link designed not for the idea of a child to promote but the idea of a society to preserve.

It is only in 1989, with the UN Convention on the Rights of the Child and of Adolescence [18], that play and recreational activities come to represent an issue with its own autonomous identity with respect to the other rights granted to the child, a matter finalized as nothing less than the promotion of the children themselves. Indeed, within the Convention, play and recreation are not only the central theme of art. 31 and the specific delineation of the principle of listening to and expression of the child, but also the particularly significant experiences - together with rest, leisure and especially fun - so that the child can «participate freely in cultural and artistic life» (italics are ours).

It now clearly emerges that gaming experiences are not only functional - but are significantly oriented - to the promotion of a child who is able to participate in common life, and to do so through free action. This emphasis on freedom is not surprising if placed within a Convention that sees the principle of listening to the child as its backbone and as a particularly significant proposal today and therefore the promotion of the child's ability/possibility to take an active part in his or her own interest, exercising as early as possible - but without forcing - one's own capacity to determine reality starting from one's self, with freedom and responsibility.

Certainly, also in this perspective the child contributes to the construction of what is common, but not in the sense of "useful to society", but of what is necessary in the name of the responsible and active exercise of their citizenship. A sense not far from what Martha Craven Nussbaum attributes to the game within the framework of her approach to skills. According to this perspective, society is just if man is placed in a position to be able to fully complete his personal definition of himself. The skills that this approach promotes are represented by «a set of (usually interrelated) opportunities to choose and to act» [19, p. 20] that are divided into ten «central capabilities» [20, p. 237] for a fully and decently lived life: life; physical health; physical integrity; the senses; imagination, thought; feelings, practical reason; belonging; life with animals, plants, nature; play; control of one's own environment. According to the approach of capacity, no capacity is a priority and, at the same time, no capacity can be left behind.

\section{THE Charter on THE Rights OF THE CHILD FACING A "CROSSROADS"}

It is precisely in the wake of this idea of the child that we find the UNESCO Charter of the Rights of Children in Sport that, not so much in the first draft of $1992^{4}$ as in the second draft of the International

\footnotetext{
${ }^{4}$ This first draft recovers the dimension of fun and play, but mainly in the sense of protection and in a much 
Charter for Physical Education, Physical Activity and Sport of 2015 [21] reconstructs a sporting experience that promotes the idea of a child able to participate actively and responsibly in the life of society contributing to its promotion in the human sense ${ }^{5}$. In fact, the «preamble» of the Charter refers - specifically in point 7 - to the idea of an ethical child who, through sport, becomes the master of enduring habits of behaviour marked by fair play, equality, honesty, excellence, commitment, courage, teamwork, respect for rules and laws, respect for themselves and others, solidarity and peace. Precisely in relation to this potential value of the sporting experience, of particular interest to the current scenario is the reference - art. 11, paragraph 2 - to sport as an experience that makes the future citizen able to actively contribute to the reconstruction and functioning of the community with particular regard to the specific experiences of «post-disaster».

The potential of sporting experience, however, is not only observed for the repercussions it may have at the level of the community, but in primis - art. 1, paragraph 6 - for the effects it may have on «human development»: «every human being» cites the Charter «must have the opportunity to reach a level of realization corresponding to their own potentials and interests». .

Reference to Nussbaumian thought is explicit, although it is not unique within the entire document. In fact, when the Charter continues the reflection and goes on to define the «benefit» that sport can offer to the child, art. 2, paragraph 6 , criteria for the recognition of the same benefit that can be placed within the framework of human capital [22] rather than human development, as previously stated. The criteria in fact refers specifically to the reduction of health costs, to the increase of the productivity of the subject, to their civic commitment and to the strengthening of social cohesion. These are criteria that recall both the WHO's Life Skills $[23]^{6}$ especially in relation to their being a premise that leads to «adaptive and positive behaviour» to «effectively address the demands and challenges of daily life» [24, p. 50], both heckmanian research, especially in relation to the confirmation that they give respect to the positive relationship between the formation of character skills of the child, and the child's future economic-social functionality as an adult.

Thus, in the UNESCO Charter on the Rights of the Child in Sport, the idea of a child oscillates between a child oriented towards their own human development and a child functional to the human capital of the nation. An evident oscillation not only in the document itself but also in the comparison between the documents on the link between sport and education. In fact, in the European Commission's White Paper on Sport [25] there is already a clear shift towards the idea of human capital and therefore towards a sport which, given a primarily social task, aims to increase knowledge, motivation, willingness to make personal efforts, personal health and the ability to participate in teamwork with fairness, observation of the rules of the game, respect for others, solidarity and discipline.

Not only in the UNESCO Charter but also in the educational landscape of recent years, the idea of a child - and therefore of a man - is faced with a «crossroads» that, with Massimo Baldacci [26], is played between human capital and human development. It is a crossroads that does not represent an alternative from time to time passable in one direction or the other. It is a crossroads that, on the contrary, requires a position regarding the idea of a child that is proposed both for its universal value and for its validity and coherence with respect to the concrete historical-cultural situation.

It is precisely to work on this position that pedagogy can enter into dialogue with sport, arguing critically in relation to the implications inherent in the two crossroads and proposing the reasons for a

more nuanced sense of the promotion of the child. Central in fact, is the attention to the removal of obstacles to the development of the child, such as the creation of a healthy, qualified and child-friendly sports environment.

${ }^{5}$ The UNESCO Charter of Rights has been outlined according to a specific sensitivity to football giving life to the decalogue of the "UEFA grassroot charter" (Basic Football Charter). The idea of human development is also recalled in the "Charter of the rights of children and the duties of adults" of the AIC (2012) in which the educational potential of football coaches finds its own horizon in the development of the sporting and human potential of the child. www.ispracalcio.com/wp-content/uploads/Archivi/Uefa-Grassroot-Charter.pdf (date of last consultation 28.06.2020). https://www.figc.it/media/2350/carta_diritti_bambini_vs_20_3_2012.pdf (date of last consultation 28.06.2020).

${ }^{6}$ Life Skills include: problem solving, decision making, creative thinking, critical thinking, effective communication, interpersonal relationships, self-awareness, empathy, emotional management, stress management. 
choice.

\section{CHOOSING HUMAN DEVELOPMENT: AS A SPORTING CAPACITY}

Not only Massimo Baldacci [26] but also Giuditta Alessandrini [27], as well as many other voices of the contemporary pedagogical world, argue that choosing the direction of "human capital" can verify «post-democratic» drifts, while neoliberals who see the child mainly as the future producer, functional to the reasons and demands of the market. At the same time, the same voices support the choice of "human development" which offers the possibility of building a democratic society based on Deweyan resurgent liberalism [26]. This implication, which is the representation of a vision of the child as a future citizen who can fully bring oneself to completion in a world that is committed to transformation in a human sense.

Precisely in view of the importance to be accorded to this second crossroads, the proposal of choice that is considered particularly promising in terms of orienting the educational potential of the sporting experience brings back this vision of the child as a person who is accomplished in himself and as an active and responsible citizen within the particular furrow traced by pedagogies and from both the critical-phenomenological and personalism philosophies. On the one hand, critical- phenomenological pedagogies and philosophies [28]-[29]-[30]-[31]-[32]-[33]-[34]-[35]-[36]-[37] are an essential reference for the epistemological framework they offer for reflection on the relationship between identity, corporeity, play and movement [2]. Secondly, the pedagogies and philosophies of personalism [38]-[39] are an essential reference for the theoretical foundations which they offer for reflection on the "child profile" [40] on the basis of which to guide the educational action of the coach and more generally of the educational professional. This child profile reconstructs what, during the course and at the end of the sporting experience, the child can come to know, to think and to know how to do [41] in the direction of that idea of athlete and citizen that it is coherent to expect for their level of development, that it is of value to expect a pledge of ethical value (to act well and for the good) and that it is significant to expect to be able to intervene effectively within the context in which one lives. It is not a matter of dissecting in detail each of the previous aspects within sequences of skills. In fact, the skills could risk being reduced only on the level of the activity, and therefore on the level of doing and performance. Instead, it is a matter of reconstructing with a broader and more integral vision the capacities that represent just as much that terrain of each individual as that of the entire human race, within which the skills of the future athlete and citizen can find both their generative act and their source of nourishment. Following the reflection of Giuseppe Bertagna on capacity, we can intend a potential and an active propensity of the human being, in our case of the student, to do, think, act [...]. The pedagogical problem becomes twofold: to ensure that everyone harmoniously realizes their best possible self [...]; no less, to ensure that each one harmoniously realizes their best abilities as men [40, pp. 23-24].

These capacities represent a terrain constituted, in primis, by that potential that must be cultivated in everyone since it represents the original and inviolable nucleus that makes a man human, and that it must be cultivated individually so that each person is able to intervene in the world for what each can in effect become and for the absolutely personal contribution that one, in all his originality, can offer.

Placing the discourse on skills within the broader framework of this inherent and original potential not only encourages an expansion of view but, in effect, a real conceptual revolution. From this perspective, in fact, skills are not established firstly on the basis of their sporting functionality-but they are distinguished in retrospect through a work of synthesis between the person - with his or her potential - and the sporting and civil world within which he or she is called to fulfil their role- with their demands and particularities. In this context, therefore, the skills have a right to be "only" to the extent that they translate those abilities operationally - in performance - which at the same time subsequently render the sports preparation, within which the child is called to exercise, significant and effective.

The utilitarian aspect of education - in that it enables the child later to work and earn a living - must certainly not be disregarded, because the children of man are not made for a life of aristocratic idleness. But the best way to achieve this practical result is to develop human capacities in all their vastness. And specialized studies that may be otherwise required must never jeopardize the essential purpose of education [38, p. 11]. 
This conceptual revolution, in order to be really as such, must be based on a clear proposal of which these potentialities are as original to the man as they are meaningful for the promotion of his personal originality. The question, pedagogically speaking, is not to dissect skills, but to «compromise in declaring what they are», today and in the sporting experience, «the skills that deserve to be best promoted, because promoted in a certain way, would create harmony and personal balance». In this sense «to think theoretically, practically and technically; [...] human life as harmonization of genetic organicity, mentality, rationality and interpersonal relationality; symbolic production» [40, pp. 25-26] represent some of the crucial capacities that, in a perspective that recalls Nussbaum thought, qualify man and open him to the possibility of full self-fulfilment.

Working on a definition of the child's profile that is coherent to expect for the child's level of development, which is of value to expect for the child's ethical-value significance (acting well and for the good) and meaningful to expect that the is able to intervene effectively within the context in which the one lives, therefore means knowing the characteristics of the child's evolutionary process, understanding what value dimensions the sporting experience can express and intentionally promote those behaviors which the child exercises in their role as an athlete and future citizen. A profile that Simone Perotta [42] begins to outline when she states:

I am convinced that we have a real and unique opportunity to build the citizens of tomorrow. Or at least we have the opportunity and the responsibility to try. Not to back out. Because the field and the game we teach them are a metaphor of life, on an ethical, cultural and moral level [42, p. 9].

\section{THE PROFILE OF THE CHILD AT THE END OF THE SPORTS EXPERIENCE}

In order to reconstruct the proposal of an architecture bearing the profile of the child at the end of the sporting experience it can be significant to recall the framework offered by the "Educational, cultural and professional profile of the student at the end of the First Cycle of Education (6-14 years)" [40]. It is a framework that lays the foundations and direction of educational experiences in school that are significant for the promotion of the child in the full and human sense. Precisely for this reason, with the necessary differentiations dictated by the rethinking of this same profile in a non-formal environment, it is a framework which can be placed with as much significance as the foundation and direction of educational experiences in sports that involve children of the same age group. The elaboration of a profile of the child at the end of the sporting experience could therefore not only orient the action of the coach in an educational sense, but also work towards the construction of a coherent, sensible and effective bridge, both within and outside school, in order to better enhance both educational areas through a system of reciprocal references.

What could be defined "An educational, cultural and sporting profile of the child at the end of the sporting experience" would not therefore have the function of predicting to the coaches what characteristics the children they are presented with will have, depending on the age group, but it would have the significance of projecting the coaches towards a possible change following the educational intervention of the coach himself.

A process of change that is aimed at accompanying the child in a phase of

fundamental passage for the construction of each person's "life project" because it provides the basis for each child to deal positively with [...] the problems of daily life and of responsible integration into family, social and civil life in this particular stage of the evolutionary age [43, online].

A process of change that, while on the one hand aims to have a positive impact on the daily life of the child and on their growth as being young and adolescent, on the other hand it also aims - as Cosimo Laneve specifies in reference to football experience - to accompany children «to become adults in the fullness of meaning» that is to promote their «human formation, helping them to develop a healthy and balanced personality that guarantees them a happy integration in social life». The "Educational, Cultural and Sports Profile of the child at the end of the sporting experience" therefore looks at the child as the person they can and must become, on the basis of their potential and in the name of an ethical-value orientation. A «person with fine sensibility, with moderate emotional openness, with acute creative intelligence, with their will rightly oriented $»[9, \mathrm{pp} .194-195]$.

Within this framework, the priority skills that the child should be accompanied to promote thanks to the educational role of the coach are: 
- to become aware of the boundaries that are being defined with respect to one's own identity thanks to the comparison with one's own limits and goals and to the constant comparison and contact with others who participate in the same sporting experience;

- to be in dialogue with one's own corporeity and to manage the relationship between the cognitive and affective profile of identity in an increasingly more and better integrated and harmonious way;

- observe and critically distinguish experience ${ }^{7}$;

- make choices and take responsibility, even if the same responsibilities lead the child to constructively manifest one's opposition in the name of an injustice or an impropriety experienced or observed;

- start a definition of one's life plan in a fluid way and operate a continuous review of the project, observing one's conditioning and the possibilities of emancipation;

- sharing and cooperating for a common objective;

- feel responsible for the personal and collective outcome;

- intervene in the sports experience to achieve a "job well done", fully exercising one's talent;

- respect for adults, companions, the environment and the rules of the game.

\section{THE TRAINER PROFILE: AN EDUCATIONAL ROLE TO PLAY}

If the profile of the child represents the horizon towards which the entire work of the coach is oriented to be educational, the coach's educational role ${ }^{8}[1$, p. 13]-[44, p. 9] starts from the awareness of both the "power" of the sporting experience to contribute to the definition of what the future adult and citizen will be, and to the particular profile of child and therefore the adult that the sporting experience must promote, in order to be educational. In fact, recognizing the coach's educational role means recognizing their awareness and ability not so much to accompany the child in a process of change tout court but rather to accompany him to change towards a specific direction.

In the light of this argument, the trainer's profile as an educator cannot be reconstructed solely from the actions and intentions of the coach himself, but it can only be thought of in the synthesis between the idea of child at the end of the sporting experience and the idea of coach that is able to foster this change: «in training, the athlete and the coach represent two interconnected elements of the same system and cannot be thought of separately» [45, p. 161]. In fact, it is precisely because of the promotion of the child in the full and human sense, that the educational role of the instructor takes on its own significance and finds its own ground of definition and articulation.

It is a promotion towards which the education works, neither placing the coach or the child exclusively at the center ${ }^{9}$ - with their tyrannical, narcissistic and solipsistic drifts -, but rather creating a common space of dialogue that sees coach and child together in the sharing of a path and a common destiny ${ }^{10}$.

\footnotetext{
${ }^{7}$ It is a central capacity within the AIC model that constitutes the theoretical frame and the field of application of the principle of participation stated in art. Article 12 of the UN Convention on the Rights of the Child and adolescence, which is the basis of the work of UNICEF, a supporter of the AIC: "States Parties guarantee to the child, capable of discernment, the right to freely express his or her opinion on any matter which interests him or her".

${ }^{8}$ Pedagogical knowledge, in fact, in particular in recent times has been asked -with Farnè- about the meaning of «identity and the role of the coach as an educator» [1, p. 13], so much as to propose -with Emanuela Isidori- a distinction between the more general pedagogy of sport and one of its facets, the pedagogy of training [45, p. 9]. ${ }^{9}$ In this we partially distance ourselves from the models of the "child at the center", such as the same AIC training model.

${ }^{10}$ Felicity Wikeley e Kate Bullock, with reference to Vygotskyan socio-constructivism, it is stated :«approaching learning purely from either the perspective of the teacher or from that of the learner is not enough [...] it is the interaction between them that, we believe, brings about learning» [4, p. 18].
} 
It is a promotion to which education works by taking a position from time to time in relation to particular dynamics that characterize the educational relationship. Among them, the priority is the antinomy between authority and freedom [46], as well as between possibility and limit, security and risk, consensus and dissent, person and group, subjectivity and objectivity, individual and society, between integration and emancipation, etc.

These are dynamics that highlight a contradiction that must be managed «without thinking of being able to solve it, of going beyond it, of proceeding to a compact and stable "new synthesis" » [47, p. 105]. The tasks of the one who educates lie precisely in the management of, and from time to time situated within, these particular dynamics, which generally concern the educational relationship in the various areas within which they are expressed and which, in particular, refer to how the educational relationship can be expressed in sports. The management mode of these dynamics can bend the role of the educator in an educational sense or keep it on a technical-tactical level or, even, exacerbate the plan itself in an authoritarian and exclusively performance related way.

The recognition of the educational role of the coach, starting from the ways of his position within the contradictory dynamics that characterize the educational relationship, is not foreign to studies in the sports field. Indeed, Robyn Jones recognizes in the coach - if the coach is an educator - the task of exercising a reflective and critical ability that allows one to take a position among contradictions that characterizes the experience: «clarification of practical dilemmas which reveal coaching's complexity, and a subsequent relevancy and directness of action» [48, p. 328].

These are dilemmas that do not make the sporting experience linear and rational but rather problematic and ambiguous: «enduring dilemmas for coaches that cannot be resolved thus generating perpetual ambiguity about which way to go. [...] such thinking could and should be integrated into future coach education programmes» [4, p. 51]. The ambiguity that specifically characterizes the sporting experience is mainly given - with Jones - by the share of pathos that accompanies the objectives that orient the commitment of the coach. They are in fact high-level performance targets, also placed in the long term with measurement and evaluation difficulties, which meet the alternation of favor and resistance by the individual athlete, requiring the involvement of an entire team, having no predetermined paths of attainment and are pursued even in the absence of the necessary information, implying at the same time a share of creativity and execution and that are influenced by internal and external factors of the team itself.

It is within the framework of this ambiguity that the dilemmas, the irresolvable contradictions of the sporting experience take shape: the athlete's tension to go beyond his limit and his fear of possible injuries, construction by the coach of a cooperative team and tension of the members to put the cooperation in second place in order to excel, the need to respond urgently to the demands of the situation and the need to reflect and weigh the situation, the importance of following the planned path and adapting at the same time to the changes required by the situation, the tension between the guidance of the coach and the involvement of athletes, openness to objectives and resistance to change: «such dilemmas within coaching are enduring, and, therefore, are not amenable to final resolution» [4, p. 57].

How much emphasis to put on team ad opposed to individual development?

To empower athletes or not and, if so, how far?

To demand strict adherence to given roles or to allow individual creativity?

\section{$[\ldots]$ how flexible should coaches be to changing circumstances?}

In the light of the above, the first and priority dynamic that calls the coach - in his educational role - to a management task is the dynamic relating to the relationship between authority and freedom, essential for a relationship that is educational and at the same time deeply rooted in the sporting experience thinking in particular of the relationship between young athletes and the coach: «the relationship between coach and athletes remains characterised by hierarchy and asymmetry» $[4, \mathrm{p}$. 53]. The coach, in fact, experienced as a "democratic" leader [49, p. 66] and of recognized value, translates his educational role in the asymmetry of roles, in his tasks of promoting respect for the rules, teaching the tactics of play, evaluation linked to the selection process, accompanying the child towards self-awareness promoted by the dynamic victory/defeat, soliciting the will to improve $[1, \mathrm{p}$. 
$18]$.

These are tasks that highlight both the authority of the coach as a guide for the child as well as the freedom of the latter to acquire an increasing autonomy within the sports path and to take action by bringing their point of view and their demands, and which require the instructor to take a position sometimes more oriented to that of authority sometimes more oriented to freedom, but always - if it is an educational position - in the name of promoting the awareness of the child and in contrast with training drifts of intimidation or emulation.

Coaches, therefore, appear caught in a dilemma. They are faced with greater calls from athletes and many scholars to share their leadership, yet in a context of accountability they are often inhibited from doing so because empowered autonomous athletes could act in ways that generate poor standards of achievement $[\ldots]$ it could negatively affect their reputation and job prospects $[49, \mathrm{p} .71]$.

Particularly significant in this perspective is the issue of error: «Knowing how to judge one's own movements and those of others, by diagnosing any errors, is one of the best means both to achieve a great technical mastery, and to ensure that the athlete participates with an increasing awareness of his training» [9, p. 192]. The matter of error, absolutely central within the experience of the sports school, highlights the relationship between authority and freedom as it calls the coach to the task of balancing from time to time the acceptance of the child for what he is and for what he could become.

It is not possible for the coach to choose only one of the two dimensions because they coexist [50] and call for the ability of the coach from time to time to take a position more oriented towards acceptance or more towards that "intelligent forcing" which represents one of his most valuable educational requirements [51].

This search for balance brings to the sports field care and attention, growing and nourishing.

It is precisely this capacity to manage the dynamic between authority and freedom which promotes an idea of a child as a future citizen, able in turn to intervene in the world through acts of freedom that can only be formed from an experience that knows how to manage the drive to autonomy and personal fulfilment while respecting the authority which is the norm of common living.

The second dynamic that calls the coach - in his educational role - to a management task, is that relating to the relationship between possibilities and limits. It is a dynamic rooted in the sporting experience of victory and defeat, which constantly confronts the coach with profound contradictions and therefore with a very difficult and continuously balanced position between the tension towards the highest level that pushes him to demand the maximum from each subject and from the team as a whole, and the attention to the fact of reality made of concrete conditions, objective limits, the unforeseen, the concrete knowledge of the subjects with which he operates» [1, p. 30].

The reality - the limit - with which sport compares the child represents an absolutely fundamental reality for a definition of identity that is realistic, therefore solidly founded, but at the same time can confront the child with disappointments and awareness that call the coach to the task of management.

At the same time, the possibility - the tension towards the highest level - compares the child with that «category of "possible" ${ }^{11},[1$, p. 31] calling the coach to the task of opening the child to the conception of a world and a man who can be transformed to become "more", who can go beyond themselves even towards high and arduous goals, sometimes improbable, still able to cultivate a great dream to be realized ${ }^{12}$ [42].

These are tasks that highlight the commitment of the coach to work both within the limits of the child

11 «In phenomenological terms, the experience of the game-played is that which teaches, directly and that is through concrete experience, the category of "possible» [1, p. 31].

${ }^{12}$ At just 13 years, leaving home, parents, friends and family is not easy. But, as they say, it's an opportunity that you can't and you just don't want to let go. You and your whole family. And you still don't know that you're about to start an adventure that, however it ends, will not only affect your life, but also that of all the people around you. Well, today I know I've made it. I've managed to fulfill my dream of becoming a professional footballer. To raise an extraordinary cup. To carry on your shoulders, many times, a "heavy" shirt; a piece of cloth that represents millions of people who are watching you. A color that is both the color of a club and the national team, is always the color of dreams» [42, p. 7]. 
- accompanying him to recognize and accept them -, as well as in the construction of a vision, open to constructing chances of success. A perspective recalled within the panorama of sports studios is that of the "proximal development area" of Vygotskij which is re-read as a possibility for the coach to accompany the child towards the border of his zone of more fruitful development [52, p. 46].

They are also tasks that require the coach to take a position now more oriented to limits - to be recognized even within victories - now more oriented to the possibility, but always - if it is an educational position - in the name of making these limits and possibilities opportunities for further definition of the identity of the child in contrast with devaluating deviations or excessive pretension of performance, that claim which - with Mantegazza - we can define «doping of the soul» [53, p. 47].

Precisely this ability to manage the dynamic between possibility and limit promotes an idea of a child as a person of «talent» [54] who knows how to intervene in the world bringing you a job well done that is done to the best of one's possibilities and for the good of one's community.

The third dynamic that calls the coach - in his educational role - to a management task is that relating to the relationship between true and right. It is rooted in the sporting experience of respect for rules and fair play ${ }^{13}$ [2, p. 93], which constantly confronts the coach with the accompaniment of the child to decide their own behavior in the field on the basis of both the rules of the game and the principles of respect for self and other. In fact, Bortolotti points out that «sport education is primarily an education to the decision» ${ }^{14}[55$, p. 103] and specifies that «To train means mainly to work in order to allow the athlete to reach the autonomy of choice of the optimal solution in the decisive moments, that is during the crucial moments of the competition» [55, p. 105]. In fact, situations of play continuously produce unusual situations for which the child must decide how to manage, so much so that Pierre Parlebas defines the motor sciences "education of motor conduct of decision".

It is a complexity that determines a stance that cannot be decided in a universal and aprioristic sense because it can be defined only from time to time. By way of example, football is called «situation sport» $[9$, p. 180] and for this reason it is considered a sport in which the «richness of tactical thought» ${ }^{15}$ is central $[9$, p. 198].

It is always said that football is a sport of situation. What does it mean to help the young footballer to develop his decision-making ability and his ability to solve problems? Is it not perhaps helping him to become, as it is now fashionable to say, even with the youngest, a "thinking footballer"? Continuously they hear coaches who, even covering "under 12s", say that the goal is to make them become footballers who... think; perhaps, it means that the instructor must try to put himself (way of being and way of acting) in such a way as to "put in position" the child and accompany him (educational path) to the choice of the solution» [24, p. 146].

"Tactical thinking" is therefore a form of thought, typical of the football athlete, already characterized by ideography, complexity, judgment in situation, pondering and choice between the unpredetermined contradictions that the situation presents, evaluation between different possible responses.

If in this decision-making process the rules of the game represent the "true" meaning the universal and objective reference point aimed at regulating the same game in all possible situations, fair play represents - in fact - the right, that is, the situational and subjective reference point aimed at interpreting, as far as possible, that same rule in the light of the specific situation and the persons involved in it. We can think, for example, of a child who is performing a promising action to score the goal of the match, but who realizes that a teammate has lost his glasses on the field: stops to save them from certain destruction thinking that their companion would have no way to easily buy a new

\footnotetext{
13 «Beautiful and fair game» [2, p 93].

${ }^{14}$ One of the factors influencing «individual technical skills» is specifically the ability to decide: «the speed of decision and execution is increasingly a fundamental, absolutely necessary factor of a high technique» [9, pp. 184, 185].

15 «Ability to perceive, understand and resolve in the most effective and appropriate way the various situations of the game, preventing and anticipating the intentions and actions of opponents. Adapt your game with ease to the particularities of the opponent, without neglecting those principles that govern the conception of the game of your team».
} 
pair. Nothing in the rules of the game tells us about this behavior, indeed it is not only unforeseen behavior but not suitable from the tactical point of view, yet it is an optimal behavior from the point of view of "right", reconstructed within the boundaries of the specific situation:

whereas the fundamental technique must essentially respond to the principles of pure mechanics and biophysics, the technique applied must also make use of the individual's mental abilities, his perception and judgment skills, the speed of his reactions, to one's power of evaluation of contingent reality [...] first stimulating the child to express judgements of an opposing nature: right wrong, success-failure. Then asking for ever more detailed and nuanced judgments [9, pp. 186, 191].

The coach, as «just and truthful» $[9$, p. 196] and being called to «act with loyalty, fairness and sporting probity» [24, p. 152], is therefore called to the task of promoting respect for the rules of the game and at the same time to decide from time to time, calibrating the rules themselves in the situation and comparing them with what is right from an ethical point of view. In fact, one dimension that marks the educational sense of the sporting experience is its ethical-value orientation ${ }^{16}$ and, therefore, its tension to work in view of the humanization of man.

\section{CONCLuSion}

The coach's task is therefore to recognize and promote the value dimensions of the sporting experience, thinking of values as guidelines for the choices of children themselves within the sports field. Pedagogy has given rise to a specific reflection on the relationship between sport and values. Starting from the framework offered by the reflections of Emanuele Isidori [2] it is possible to think of the coach as the one who has the task not only to recognize and transmit but also to observe the question, the values themselves in a critical and heuristic way by questioning dimensions commonly misunderstood as values and looking for those new ethical aspects that should guide sport to increasingly be the test bed for the adult and the citizen of tomorrow ${ }^{17}$. If among the values that are recognized today from the sporting experience, the group spirit and camaraderie, loyalty, dedication to the team, self-control, respect for discipline and rules, humility, trust, perseverance, spirit of sacrifice, courage, will, effort, competitive spirit, discipline, physical and mental health ${ }^{18}$, we can recognize among the new practices of value which should be conceived for sport, we find - again with Isidori - the possibility of competitions without national divisions or without gender divisions, a real movement in favour of equality and parity in the athletes' starting conditions before a competition thus excluding the use of doping - a work of transformation of the attitude of spectators and fans in the direction of respect and inclusion [56]-[57]-[58]-[59]-[60]-[61].

These are values that highlight the task of the coach to work both in respect of the truth - the universal rules of the game - as well as in respect of the right - what preserves a deeply human value within the particular situation. It is a task that requires one to take a position that takes into account from time to time both the truth and what is right, directing the decisions of the instructor and the child in the name of - if it is a statement of educational position - the ethical value of the decisions themselves, in contrast to any relativism or nihilism.

It is precisely this capacity to manage the dynamic between true and just that promotes an idea of an ethical child, able to intervene in the world with «constructive, honest and rigorous attitude» (Art. 4) ${ }^{19}[62]$.

\section{REFERENCES}

[1] Farné R. (Ed.), Sport e formazione, Milano: Guerini Scientifica, 2008.

[2] Isidori E., Pedagogia e sport. La dimensione epistemologica ed etico-sociale, Milano: FrancoAngeli, 2017.

[3] Miatto E., L'allenamento come accompagnamento e pratica personalizzante, in Isidori E., Aranda Fraile A.

\footnotetext{
${ }^{16}$ Sport $[\ldots .$.$] needs, like every human practice, not only the clarification and awareness of the aims it intends to$ pursue, but also the justification of the means and methods it uses to pursue them» [44, p. 22].

17 «Finding new ethical content and new values is the main task of pedagogy as a regulatory science» [2, p 19].

${ }^{18}$ They could be the same values respected by a criminal organization [2]: the difference is given by the orientation towards the good. In any case, can we define value as how much is not oriented towards the good?

${ }^{19}$ Idea of Fair Play that is also recalled within the Ethical Charter of Sport in Piedmont (2017) with particular regard to the educational dimension: «constructive, honest and rigorous attitude» (Art. 4).
} 
(Eds.), Pedagogia dell'allenamento. Prospettive metodologiche, Roma: Nuova Cultura, 2012, pp. 77-96.

[4] Jones R.L., Wallac M., The coach as 'orchestrator'. More realistically managing the complex coaching context, in Jones R.L., The sports coach as educator: Reconceptualising sports coaching, Abingdon-OxonNew York: Routledge, 2006, pp. 51-65.

[5] Refrigeri G., Sport professionistico come sublimazione di attività belliche, in Milani L. (Ed.), A corpo libero. Sport, animazione e gioco, Milano: Mondadori, 2010, pp. 87-101.

[6] Milani L. (a cura di). A corpo libero. Sport, animazione e gioco, Mondadori, Milano, 2010.

[7] Arnold P.J., Educazione motoria, sport e curricolo, Milano: Guerini, 2002.

[8] Rawls J., Una teoria della giustizia, Milano: Feltrinelli, 1989.

[9] Laneve C., Il campo della didattica, Brescia: La Scuola, 1997.

[10] Spranger E., La vita educa, Brescia: La Scuola, 1965.

[11] Lombardozzi A., Il ruolo dell'allenatore in prospettiva pedagogica, in Isidori E., Aranda Fraixe A. (Eds.), Pedagogia dell'allenamento. Prospettive metodologiche, Roma: Nuova Cultura, 2012, pp. 49-75.

[12] Gamelli I., Pedagogia del corpo, Roma: Meltemi, 2011.

[13] Laberthonnière L., Teoria dell'educazione e altri scritti pedagogici, Brescia: La Scuola, 1901/2019.

[14] Janusz Korczak, Il diritto del bambino al rispetto, Milano: Luni, 1929/1996.

[15] Società delle Nazioni, Dichiarazione dei diritti del fanciullo, Ginevra, 1924, www.images.savethec hildren.it/f/download/CRC/Co/Convenzione_1924.pdf (04.05.2021).

[16] Lega internazionale per l'educazione nuova, Carta dell'infanzia, Londra, 1942, www.liberamente.pr.it /Cartainfanzia.htm (04.05.2021).

[17] Assemblea Generale delle Nazioni Unite, Dichiarazione Universale dei Diritti del fanciullo, New York, Novembre 1959, www.images.savethechildren.it/f/download/CRC/Co/Convenzione_1959.pdf (28.11.20 20).

[18] Assemblea Generale delle Nazioni Unite, Convenzione sui diritti dell'infanzia e dell'adolescenza, New York, November 1989, www.unicef.it/convenzione-diritti-infanzia/articoli/ (04.05.2021).

[19] Nussbaum M.C., Creating Capabilities. The Human Development Approach, Cambridge-MA: Harvard University Press, 2011.

[20] Nussbaum M.C., The Monarchy of Fear: A Philosopher Looks at Our Political Crisis, New York: Simon \& Schuster, 2018.

[21] Unesco, Carta Internazionale per l'Educazione Fisica, l'Attività Fisica e lo Sport, 2015, https://unesdoc .unesco.org/ark:/48223/pf0000235409_ita (04.05.2021).

[22] Heckman J.J., Kautz T., Formazione e valutazione del capitale umano. L'importanza dei "character skills" nell'apprendimento scolastico, Bologna: Il Mulino, 2016.

[23] Organizzazione Mondiale della Sanitá, Life skills education in schools, Ginevra: Who, 1993.

[24] Ghisleni S. (Ed.), Scuola di calcio. Scuola di vita. Manuale tecnico-educativo per le Scuole Calcio, Bologna: Minerva, 2017.

[25] Commissione della Comunità Europea, Libro bianco sullo sport, Bruxelles, 2007, https://eur-lex.europa.eu /legal-content/IT/TXT/PDF/?uri=CELEX:52007DC0391 (04.05.2021).

[26] Baldacci M., La scuola al bivio, Milano: Mondadori, 2019.

[27] Alessandrini G., Lavorare nelle risorse umane, Roma: Armando, 2019.

[28] Bertolini P., L'esistere pedagogico. Ragioni e limiti di una pedagogia come scienza fenomenologicamente fondata, Firenze: La Nuova Italia, 1988.

[29] Bertolini P., Caronia L., Barone P., Palmieri C., Ragazzi difficili. Pedagogia interpretativa e linee d'intervento, Milano: Franco Angeli, 2015.

[30] Cambi F., Abitare il disincanto. Una pedagogia per il postmoderno, Torino: Utet, 2006.

[31] Gadamer H.G., La responsabilità del pensare. Saggi ermeneutici, Milano: Vita e Pensiero, 2002.

[32] Gadamer H.G., Bildung e umanesimo, Genova: Il Melangolo, 2012.

[33] Gadamer H.G., Educare è educarsi, Genova: Il Melangolo, 2014.

[34] Ricœur P., Filosofia della volontà. Il volontario e l'involontario, Genova: Marietti, 1990.

[35] Ricœur P., La persona, Brescia: Morcelliana, 1997.

[36] Ricœur P., Percorsi del riconoscimento. Tre studi, Milano: Raffaello Cortina, 2005.

[37] Ricœur, P., Il Giusto. Vol. 2, Cantalupa (TO): Effatà, 2001/2007.

[38] Maritain, J.J., L’educazione al bivio, Brescia: La Scuola, 1942/1966. 
Rethink the Educational Potential of the Sporting Experience for the Child between 5 and 11 Years: The Educational Tasks of the Coach

[39] Mounier E., Traité du caractère, Parigi: Seuil, 1947.

[40] Bertagna G., Valutare tutti, valutare ciascuno, Brescia: La Scuola, 2004.

[41] Baldacci M., Curricolo e competenze, Milano: Mondadori, 2010.

[42] Perotta S., Il calcio è la mia vita, in Ghisleni S. (Ed.), Scuola di calcio, Scuola di vita. Manuale tecnicoeducativo per le Scuole Calcio, Bologna: Minerva, 2017, pp. 7-10.

[43] Ministero della Pubblica Istruzione, Profilo educativo, culturale e professionale dello studente alla fine del primo ciclo di istruzione (6-14 anni), All. D, 2004, https://archivio.pubblica.istruzione.it/ministro/ comunicati/2004/allegati/all_d.pdf (28.11.2020).

[44] Isidori E., Fraile E., Educazione, sport e valori. Un approccio pedagogico critico-riflessivo, Roma: Aracne, 2008.

[45] Isidori E., Dax Mündiger Trainer a coach critico-rifessivo. Prospettive pedagogiche per ripensare l'allenatore come educatore, in Isidori E., Aranda Fraixe A. (Eds.), Pedagogia dell'allenamento. Prospettive metodologiche, Roma: Nuova Cultura, 2012, pp. 151-185.

[46] Baldacci M., Trattato di pedagogia generale, Roma: Carocci, 2012.

[47] Cambi F., La questione del "soggetto" come problema pedagogico, in Studi sulla Formazione, XI, 2 2009, pp. 99-107.

[48] Jones R.L., Studies in Sports Coaching, Cambridge: Cambridge Scholars Publishing, 2020.

[49] Jones R.L., Standage M, Shared leadership in the coaching context, in Jones R.L. (Ed.), The sports coach as educator: Reconceptualising sports coaching, Abingdon-Oxon-New York: Routledge, 2006, pp. 65-76.

[50] Gronn P., Distributed Properties: A New Architecture for Leadership, Int. Educational Management \& Administration, 28(3), 2000, pp. 317-338.

[51] Adorno T., Educazione dopo Auschwitz, in Donaggio E. (Ed.), Adorno, Fromm, Horkheimer, Löwenthal, Marcuse, Pollock. La Scuola di Francoforte. La storia e i testi, Torino: Einaudi, 1966/2005, pp. 261-279.

[52] Potrac P., Cassidy T., The coach as a 'more capable other', in Jones R.L. (Ed.), The sports coach as educator: Reconceptualising sports coaching, Abingdon-Oxon-New York: Routledge, 2006, pp. 39-50.

[53] Mantegazza R., Con la maglia numero sette. Le potenzialità educative dello sport nell'adolescenza, Milano: Unicopli, 1999.

[54] Benetton M., Valori e disvalori educativi nell'allenamento, in Isidori E., Aranda Fraile A. (Eds.), Pedagogia dell'allenamento. Prospettive metodologiche, Roma: Nuova Cultura, 2012, pp. 97-118.

[55] Bortolotti A., Autonomia e dipendenza nel rapporto fra allenatore e atleta, in Farné R. (Ed.), Sport e formazione, Milano: Guerini Scientifica, 2008.

[56] Roversi A., Tifo, calcio e violenza, Bologna: Il Mulino, 1992.

[57] Roversi A., Calcio e violenza giovanile, in Ulivieri S. (Ed.), L’educazione e i marginali. Storia, teorie, luoghi e tipologie dell'emarginazione, Firenze: La Nuova Italia, 1997, pp. 191-196.

[58] Dal Lago A., Moscati R., Regalateci un sogno. Miti e realtà del tifo calcistico in Italia, Milano: Bompiani, 1992.

[59] Dal Lago A., Descrizione di una battaglia. I rituali del calcio, Bologna: Il Mulino, 1990.

[60] Triani G., Mal di stadio, Roma: Edizioni associate, 1992.

[61] Triani G. (Ed.), Tifo e supertifo. La passione, la malattia, la violenza, Napoli: ESI, 1994.

[62] Comitato Scientifico Etica e Sport, Carta etica per lo sport piemontese, Torino, 2006, www.comune.torino. it/pass/php/4/img/sport/Eventi/carta_sport.pdf (04.05.2021).

Citation: Emanuela Guarcello. "Rethink the Educational Potential of the Sporting Experience for the Child between 5 and 11 Years: The Educational Tasks of the Coach" International Journal of Humanities Social Sciences and Education (IJHSSE), vol 8, no. 7, 2021, pp. 211-225. doi: https://doi.org/10.20431/2349. 0381.0807024

Copyright: (C) 2021 Authors. This is an open-access article distributed under the terms of the Creative Commons Attribution License, which permits unrestricted use, distribution, and reproduction in any medium, provided the original author and source are credited. 